\title{
Some Trace Remains (An Extract)
}

\author{
MADELEINE FULLARD
}

\section{I}

\section{WINTERVELD}

January 2005. Winterveld is my first cemetery, and it teaches me everything. Day after day, it takes my assumptions, theories and plans and grinds them into the fine dust that eddies in small puffs around the graves in the late afternoon, when the heat cools and a small breeze picks up. Vast, swollen, Winterveld defies all principles of linear and numerical order. Over the years, the cemetery strains and bursts its seams. Graves creep towards the rough fences and the dirt road.

Standing at one end, it is not possible to see where the cemetery ends. It is as if some curvature of the earth conceals its limits. It will take you twenty minutes to weave through the graves, shrubs, low trees and thorny grass to get to a point where you can see the opposite side. You may think you are in a rural area, judging from the sounds of livestock, the vegetation, the small plots and scattered homesteads, but Winterveld is just north of Pretoria, right on the periphery of the townships of Soshanguve and Mabopane.

It is an unassuming cemetery. Some of the intermittent tombstones are formal granite structures, but most are rough homemade markers, cobbled together with bricks, cement and wood. Many graves are marked only by low mounds of soil, edged with stones picked up in the nearby fields, often adorned with a few old porcelain cups and enamel plates. These chipped pieces of crockery are the most frequent markers of mourning here: this was his cup, this was her plate.

Somewhere in this cemetery lie the remains of ten students, known as the 'Mamelodi 10', as well as eight other residents of the Pretoria township of Mamelodi. All eighteen vanished on various dates between 1986 and 1988. Their families knew nothing of their fate until 1996, when members of the Northern Transvaal Security Police and the South African Defence Force applied for amnesty from the Truth and Reconciliation Commission for their deaths. Stolid ageing white men and their junior black colleagues stood before the Commission's Amnesty Committee, and members of the affected families, and described the murders in vague but scalding detail. The Mamelodi 10 were drugged and burnt to death. The other eight were strangled or electrocuted and their bodies blasted into fragments with the help of limpet mines. One was burnt. The perpetrators' recollection of names, dates and locations was poor, perhaps deliberately so. 
Although the families now knew the fate of those who had disappeared, the whereabouts of the bodies remained unknown. They were in limbo - dead, but missing.

There were - in South Africa at least - two possibilities for those who were abducted and killed by the security forces. The first was that perpetrators secretly disposed of bodies in concealed places known only to themselves. Here, there is little chance of finding the remains without information from the perpetrators themselves. The second was that - like the Mamelodi 10 - the bodies were left in a public place without any effort at concealment. Unless left in a very remote area, such bodies were usually found and reported to authorities.

The bodies would be collected and taken to a mortuary and, if not identified or claimed, they would be buried as paupers in municipal cemeteries. In these cases, a significant paper trail can often be followed - police reports, mortuary registers, cemetery books. These bodies can be traced without the assistance of the perpetrators.

Prior to the establishment of the Missing Persons Task Team, investigators from the National Prosecuting Authority had done significant groundwork on the Mamelodi 10 case, tracing the mortuary registers, police reports and municipal burial orders. According to these documents, undertakers had removed the ten unidentified burnt bodies from the Garankuwa mortuary for burial on 31 July 1986, five weeks after their death, along with six other paupers.

The mortuary book states that the intended place of burial was Winterveld Cemetery.

The old Winterveld Cemetery is still run by a local tribal authority - a remnant of the Bophuthatswana bantustan structures. A few kilometres from the cemetery, members of the tribal authority - a group of old men - sit and deliberate in a row of dark rooms in a building that is crumbling around them. The new Winterveld Cemetery, not far from the old one, is controlled by the Tshwane metropolitan municipality but the Tribal Authority has held onto the old one. A battle is raging, as the municipality tries and repeatedly fails to wrest the old cemetery from the Tribal Authority and bring it under municipal control. The old men are not letting it go, even though there is no more space in the old cemetery. Cemeteries generate income: grave sites are sold.

The tribal authority has a handwritten exercise book listing names and grave numbers for the old cemetery up to 1986. This semblance of order in a lined school book, deaths marching chronologically with date and number, suggests a quick and easy recovery. The ten unknown bodies must be inscribed in the book with their assorted grave numbers.

We plan to first map and mark the graves. Arriving at the cemetery early, armed with the grave numbers neatly copied onto our clipboards, we are crushed by the end of the morning. No numbers and no order is evident in the cemetery. What we seek is unmarked, and now almost invisible beneath an upheaval of green summer grass that reaches our thighs. 
Defeated by the heat and hours of bending, checking, marking, we slouch listlessly, leaning back against rough tombstones, clipboards cast aside, pens sliding into the undergrowth.

'But surely -

'Why didn't they -

'Perhaps we can -

We learn that the strict numerical order in the book is not reproduced in the cemetery itself. You got your little aluminium metal stick with a number engraved on it, and you chose a gravesite from among those that had already been dug by gravediggers, tucking the marker at its head. The grave number, say 456, might find itself rubbing shoulders on each side, and above or below, with quite different numbers.

Then, in a disaster that swept through many cemeteries across the country in the late 1990s and early 2000s, the little metal markers were stolen and sold for scrap metal. Thieving hands probed the soil at the head of the graves and prised out the precious metal sticks with their numbers. In exchange for a few rand from a scrap-metal dealer, a cemetery that was not strictly chronological was rendered unreadable.

We start scratching at the heads of graves, pulling out grass tufts and ferreting in the shallow mounds, and find a few metal markers that escaped removal. This barely helps. Numbers were also reallocated. Somewhere between numbers 300 and 500, the sequencing reverts back to 1 and start again. And, while most cemeteries are laid out horizontally - graves dug side by side, the dead buried shoulder to shoulder Winterveld moves largely vertically, placing the dead head to toe.

We have yet to discover that this is how it will be all across the country. This is the start of a power struggle with intractable earth and stone, each cemetery with its own indifferent refusals and immutable disregard.

We trace and interview an assortment of individuals all over Winterveld and Mabopane who have worked in the cemetery at some stage: undertakers, grave diggers, caretakers, the tribal authority elders. Yes, they recall those ten burnt bodies. It was a rare event. They were put in coffins which were loaded on a bakkie and taken to the cemetery. Oh yes, they remember those bodies.

'Can you show us where they were buried?'

They will try. We arrange to meet at the cemetery later that week. Surely, this concentrated gathering of memory would coalesce into an identified burial place.

They arrive at the cemetery in pairs, in groups, alone. They eye the cemetery as if seeing a strange beast for the first time. They tramp up and down, examining tombstones. One points to a flattish area near the road: this was a pauper section. Others head off to side segments of the cemetery. There are different theories, different sites. They argue as to whether the bodies were buried two to a coffin, or each in their own. No one remembers their burial place. For those who labour with heavy soil 
under a hot sun week after week burying hundreds of the dead, graves become as unmemorable as paving stones.

One cemetery worker, though, does recall some investigators coming to the cemetery years before, prior to the theft of the grave numbers. He thinks they found an area near a tree at the rear end of the cemetery. We walk to the tree and he points out a rough unremarkable linear area without any tombstones. It looks more like a narrow footpath. We finger and probe the surfaces of the graves and soil heaps in that area, eliminating those where we find any trace of human care.

And there, beside a low euphorbia tree with poisonous milky sap, is a small gift the only one we will ever receive in Winterveld. One metal marker is found peeping out at the head of a flat grave: it bears the number A155. The number is one of the six allocated to the paupers who were buried with the Mamelodi 10. It is not one of the Mamelodi 10. But they should be nearby. We resolve to open the flat unmarked graves in the vicinity, and we invite the family members of the Mamelodi 10 to witness the process. 


\section{PHOTOGRAPHS}

The night before you leave your safe house in Lusaka to infiltrate the country, Ambrose tells me, you give away your few precious things. This shirt, that watch. Attachment to things is meaningless now. You give them to those around you. Take this. Give that to so-and-so. It is understood - but never said - that you will probably never return. The car arrives to take you to Zimbabwe, from where you will cross into Botswana. It is time to say goodbye. You laugh and embrace those staying behind, showing a confident exterior. The car pulls away, the house recedes behind you, and you turn to face the road ahead.

\section{'You knew you might die?'}

'Oh yes. But I wanted to fight.'

In the frontline states - Botswana, Zimbabwe, Swaziland, Lesotho - bags for your underground life are prepared. If you are heading to Johannesburg or other metropolitan centre, you will carry only clothing and money. You will quietly hop the border fence into South Africa, and then continue, via public transport or in a car, to your destination - say, Katlehong or Soweto. Arms will be provided to you inside the country from caches established by others. But if you are embarking on a rural mission, crossing the borders to walk across farms and dirt roads to a site deep in the countryside, your bags will include weaponry: grenades, AK-47s, limpet mines.

When you are captured or killed after infiltrating the country, your bag of goods will be minutely examined by the security police. It is evidence, and it teaches them what to look out for. Everything is photographed and itemised. The blue overalls, the Grasshopper boots, the tinned beef, the Botswana currency forgotten in your pocket.

The security police did not have their own photography section. Instead, they relied on the plaaslike vingerafdruk kantoor (local fingerprint offices) located within each police division. Known by the acronym, PVAK, each province had several such offices, and they handled both fingerprints and photographs. Their regular duties involved photographing crime scenes, car accidents, suicides, murders. They were also used by the security police to photograph political protests and funerals, scenes of arson attacks, the aftermath of skirmishes between underground operatives and security forces. They photographed the scenes of death - bodies at the site - and bodies at the mortuary. All negatives and prints were placed in thin brown folders with their own file numbers.

During the four years of political negotiations in the early 1990s, the security police destroyed a vast number of documents. The PVAK photographic records, however, located as they were within regular criminal policing, were left untouched. After 1994, when the PVAKs were restructured and renamed as Local Criminal Record Centres (LCRCs), the old photographic dockets and negatives became part of the LCRCs' archives. 
The PVAK in Ermelo covered areas in what was the old Eastern Transvaal police division - now largely Mpumalanga province - including the towns of Bethal, Standerton, Amsterdam, Evander, Secunda, Carolina and Piet Retief. Its successor, the LCRC, has remained in the Ermelo Police Station, and boxes filled with old photographic dockets line the very last office beside the back door - their next move will likely be to a shed in the police station's backyard.

I am looking for photographs of an incident in January 1983, in which two members of the ANC's armed wing, uMkhonto we Sizwe (MK) were shot dead in Piet Retief. In an old mortuary book from the town, I've found entries for their post-mortems and notes of their cause of death - identical single gunshot wounds to the heart. I have also traced their pauper burial sites. But their identities remain unknown. I'm hoping that the scene was photographed by the Ermelo PVAK, and that their faces will be visible.

The Ermelo station commander is on leave, and a young policeman is acting in his position. He is not sure if it is permitted, but allows me to spend a feverish day on the floor in the back room, searching through the hundreds of files. Among records of culpable homicide and theft, my hands find terrorism, sabotage, public violence. There is no time to scrutinise each file. I can only glance at the covers and toss promising ones in a pile. I scribble out a list of roughly a hundred files for the uncertain acting-station-commander, throw them in the car and flee.

The snatched files contain treasures, both hoped for and unimagined. The photographs of the two MK members shot dead in January 1983 are there, with clear prints of their faces that allow us to identify them as Vusumzi Justice Ngwema and Mziwamadoda 'Madoda' Richman Bonga. Each body has a neat single-entry wound to the heart area. Precious and unique markers for identification are visible on the two bodies lying naked on the wet mortuary floor: Vusumzi has a false tooth, and Madoda has a black bracelet around his lifeless arm. Both articles are found in the grave when we exhume them.

Another file contains black and white prints of three dead men, clad in overalls and dungarees, sprawled beside a small pickup truck stuck in a narrow ditch. They are the three MK members killed in November 1985 after they attacked the Sasol oil refinery: Barney Molokoane, Victor Khayiyana and Vincent Sekete. Barney Molokoane is a most celebrated and mourned MK member, and was part of MK's special operations unit. It was his third attack on Sasol. Both the incident and cause of death have long been shrouded in rumour. Several biographies state that the three were killed by napalm.

'Napalm?' I asked incredulously on first hearing the allegation. Napalm is delivered via aerial incendiary bombs or flame throwers. 'That's not possible. The South African security forces were never issued with napalm.'

The photographs show that all three died of bullet wounds.

The images in the Ermelo PVAK photographic files are painful in their indifferent angles and cool gaze. Bodies and objects are photographed with the same casual disregard. There are photos of four bodies at the mortuary, their bodies pocked with 
bullets following a security-police ambush of a vehicle near Piet Retief in June 1988. Their white Toyota Corolla, punched with the same automatic-weapon fire that punctured their bodies, is shown in the yard of the police station. The four had just crossed the border from Swaziland.

The Ermelo PVAK collection also includes photographs of political protests by ordinary civilians in what used to be known as the Eastern Transvaal. The perspective of the photographs is compellingly inverse: it is the view from within the police vehicles, looking out onto the street. A set of black and white photographs from 1985, of a protest in Bethal, captures an exuberant scene of motion amidst everyday life in eMzinone township, framed by the wire mesh of a police vehicle. A washing line, pegged with clothing, waves in the wind in the yard of a township house. Two young boys watch the protestors. One leans cockily against the fence, hand on hip, barefoot and in shorts. The other stands back at a more secure distance, leaning flat against the wall of his house. The skirt of a young woman in the street swirls as she turns to look at her fellow protestors. A few young men are in front, rhythmically synchronised in a toyi-toyi, knees raised in identical fashion. The police van is within meters of them, the camera is trained at them. It is a picture of fearlessness in motion, an infectious rebellion, ordinary residents in revolt. Without the frame of a police van, the scene could be celebratory, festive.

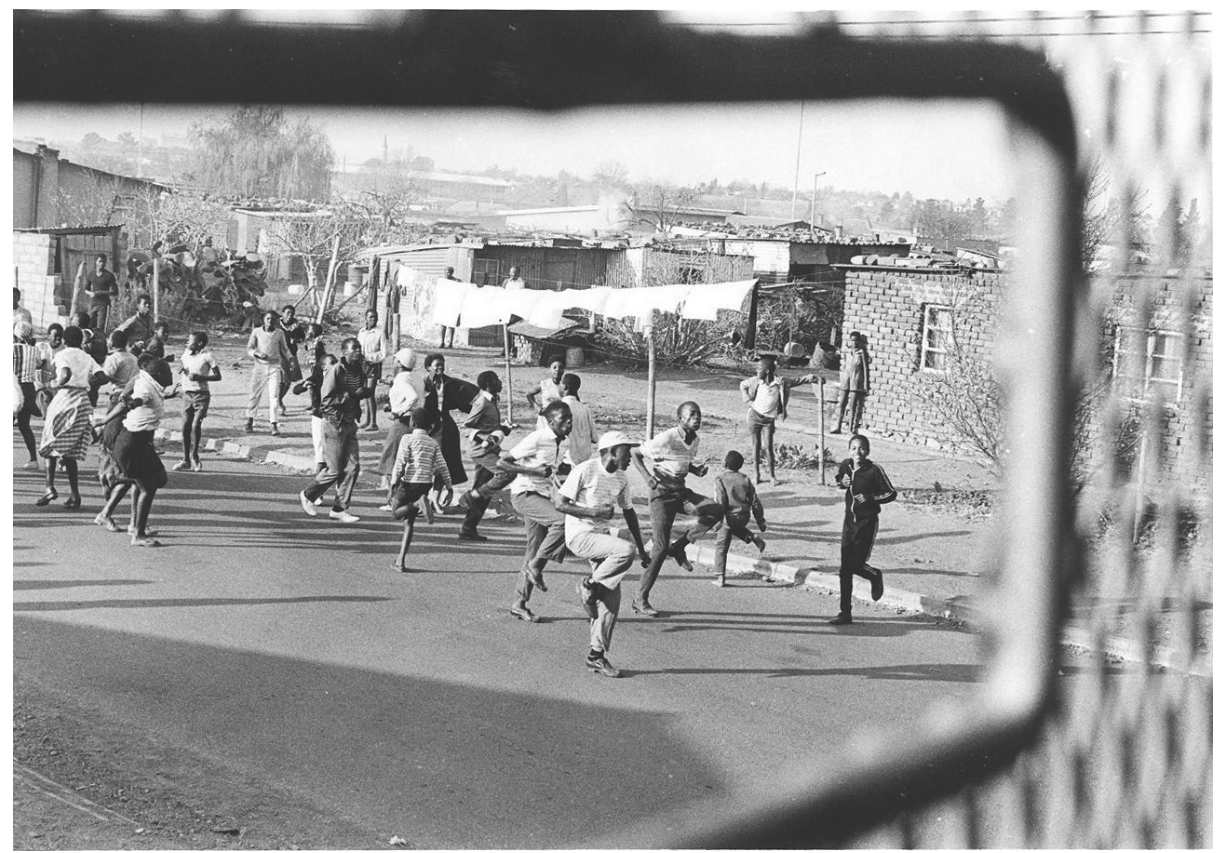

Unidentified police photographer, PVAK, Ermelo.

In Standerton, residents attending a political funeral in 1985 travel in a slow convoy of vehicles heading for the cemetery, fists in the air. The long line of cars, taxis and trucks stretches into the distance. Some residents walk alongside the car, including 
two older women. The disregard for the police camera, the dismissal of state authority, is palpable.

The PVAK photographs are taken with a focus on evidence. They are to be used to charge and convict offenders, to provide proof or show reasons for police actions. A young man has been shot dead by police during a political protest and the photo of his body shows a cluster of small stones beside him: evidence of his illegal behaviour. He was throwing stones. They are a little too neatly arranged beside his lifeless form. The animation evident in these photographs contrasts with the grim mortuary scenes and motionless bodies of the dead, yet they are intimately connected. They are simultaneous events, showing the anatomy of a revolt, in both its living and dying.

The Ermelo PVAK photographs are mainly black and white. An old white policeman, who served as a photographer in Germiston, tells us that, in the old days, their unit would use black and white photographic film for black people and colour film for white people. He shakes his head, marvelling, ashamed in retrospect.

The Pietersburg PVAK, now called the Polokwane LCRC, has photographs of the bodies of five MK members lying in the bush in rural Limpopo. All five died in a skirmish with South African security forces on 3 August 1988 near the northern border area of Alldays. Two are shot dead, three are terribly damaged by explosives. Weaponry is scattered amidst and beside the bodies. Ambrose, Brian and John study the almost intolerably gruesome photos for hours. It could have been them. After they become accustomed to the bodies and their injuries, they look beyond them to other aspects in the photos: the terrain, the weapons, the clustering.

'No way. It's impossible. Look at this one. Two RPG rockets lying right next to his skull? And these landmines lying around? Why would they do that?'

After each incident the bodies were also photographed at the mortuary in perfunctory fashion, lying on metal body trays. There was no systematic photographing of each injury. We are lucky if the face is visible. By contrast, the bags and weapons found at the scene are scrupulously attended to. Each bag found with the dead is carefully unpacked at the police station and its contents laid out on a blanket on the floor in an office, or on a dull brown carpet.

The Security Police neatly photograph the weapons recovered with six MK members shot dead in an ambush on 10 July 1986 near Alldays in Limpopo province:

Six AK-47s

Twenty-four AK-47 magazines

Six limpet mines

Six defensive grenades

Six offensive grenades

Twelve grenade detonators

Two Makarovs

Three magazine clips

Two boxes of bullets 
The laying out, organising and listing of the military hardware and associated items imposes order and control. Weapons are separated from the more personal items and photographed with linear precision and in clear numerical detail.

The dead men have meaning only in terms of these insurgent objects. Yet the photographs also unwittingly humanise them. Clothing, food, and personal items are photographed too. These items have a particularity that carries the intimate mark of human selection: this jersey, those thick striped socks, this underwear, for the mission.

There are provisions. Three tins of canned beef. An open packet of Eet-Sum-Mor biscuits. A tin of canned peaches. Sixteen apples. A packet of Simba cocktail peanuts. The police docket lists various food items including Provita, biltong and dry fruit in plastic bags, tins of fruit juice. A flat box of Consulate cigarettes.

There are small items of personal care. A toothbrush and a wash rag. A pair of nail clippers. A tin of brown shoe polish.

There are minor medical supplies: bandages, Elastoplast, Germolene ointment. One bag holds an asthma pump and medication. The first-aid items gesture to imagined survival and the nursing of wounds, bites and scratches. The small roll of gauze bandage and pack of plasters exist in gross juxtaposition to the bodies of the dead, irreparably damaged, with their heads shot open and hands blown off. The disparity between medical precautions and final fate is excruciating.

The security police also note amounts of money recovered with the dead. A group of four has R350 (perhaps R10 000 in today's terms) plus some Botswana pula and tebe in their pockets.

These little preparations, the careful folding of items, a pocket book of notes, three pencils: all are delicate signifiers of care and intent. The photographs show the bare material life and journey of an underground guerrilla, weaving into South Africa across the rural border areas of Botswana, Swaziland, Lesotho or Zimbabwe, and its abrupt end. The contents of the bag are as inert as the corpses, stopped dead in their tracks. The apples and polony will rot as surely as the bodies. The mission lies in ruins. Bodies in the mortuary; bags and belongings become detritus on the policestation floor. 


\section{DNA}

The skeleton is lying on the table. A little damp from years in the dank earth, he has been slowly drying in the natural air for a week or so. We are patient: any heat or direct sun may cause uneven contraction and cracking of the bones.

When he is dry, Billy, Ambrose, Brian and John pull on surgical gloves and cluster around the table with small brushes - paint and tooth brushes - and thin wooden sticks. Each selects a bone cluster and get to work brushing off the earthy residue that crusts around the bones in an organic shroud, a filmy soil mantle. They take care with any flaking or crumbling edges, particularly where these reflect fractures or injuries. A wooden stick is used to prod at the harder soil packed into hollows and cavities, loosening it for removal with a brush. The bones must be exposed, bare and naked, for closer scrutiny.

In the early days they worked silently, in some awe and apprehension. Now, accustomed to working with human remains and practiced in their brushing, they fall into conversation. Billy and Brian are in perpetual argument: in the car, in the cemetery, here with the bones. There is only one subject - the state of the ANC and its government - and it gets heated. Billy is critical and impassioned, Brian more measured, cautious. John joins the fray with enthusiasm. Ambrose is quieter, a torn loyalist. White-gloved fingers and dusty brushes are raised and pointed as the argument heats up. They're discussing revelations that nearly R250 million has been spent upgrading President Zuma's private residence using state funds, as well as other ongoing corruption scandals and allegations. The skeleton, who might be horrified to hear what he died for, says nothing. His own physical disintegration laid out before them, though, is a silent mirror of their conversation, akin to the decay of the liberation movement that so grieves them.

Beside the skeleton, I feel I am in the presence of a distant relative, familiar but not quite familial. It is as if I detect a kinship, but of someone a little estranged. A fleshed corpse with its loss of animation is a step away from the human - decomposition dropping a visceral curtain of mortality. A skeleton is even more distant.

The loss of flesh and face renders bones generic, with little individual identity. A once-recognisable subject has become object. The bones themselves, once alive, teeming with nerves, blood vessels and marrow, are now also dead. The dry inanimate shell only gestures to the human being he once was. He is now only remains, remnants.

His bones radiate out from the vertebrae of his spine. The vertebral column is the connective tissue we share with fish and fowl, mammal and lizard. Here I see our animal place, a mutual architecture built over millions of years. We are vertebrates together, all built along that spiny segmented column, mouth at the top, anus at the end, gastrointestinal tract in between. Spread out on the table, links to our bony animal companions are laid bare. We differ only in the shape and size of our infrastructure.

The erosion of his umber brown bones, their edges perpetually softening, is slowly bringing him closer in appearance and substance to the roots and soil we plucked 
him from. Decomposition returns us to our affinities with flora and fauna. He is becoming earth, journeying from human to dust. His corporeal compounds are reverting to their original simple substances: salts, minerals, proteins and phosphates, the constitution of life dissembling back to the earth.

Bones are an archive, unreadable to those of us unschooled in their language and codes, but rich in detail to forensic anthropologists. Kavita and Kundi print out copies of their forms, preparing to scrutinise the bones and note their findings. Laché has recently left us to join the police forensics division, which is, at last, starting to employ forensic anthropologists. The forms have diagrams, codes, and measurements that will whittle down his possible identity to fewer options. Kundi puts on the white lab coat from her student days, painted with medical words in blue and orange and red. She has something of a germ and dirt phobia and never works without gloves. Kavita doesn't care much for protective clothing or gloves. When her baby was born, she brought her to the office to greet both her colleagues and the skeletons. Shivani perched on the edge of the table and gurgled and waved at the bones beside her, her mother looking proudly down at her baby and the dead young man she was working on.

The first task is to do an inventory of the bones: which are present, which are absent, which, if any, were lost or destroyed around the time of death (peri-mortem) or have subsequently disintegrated in the earth (post-mortem). They fill in the forms and colour in diagrams of the skeleton and individual bones, marking peri-mortem losses in red and post-mortem losses in green.

They establish his age at the time of death by examining the state of fusion between various bones, which unite at different ages. They look at the wear on his teeth. Depending on the condition of the bones, and the presence of key bone ends, they can sometimes narrow the age range to a couple of years. If the required bones are eroded, they may only be able to say he is aged somewhere between twenty and forty, or, worse, only that he is an adult. This skeleton has some strong age markers.

'Definitely under thirty, I'd say.'

'Maybe even under twenty-five. Look at this ...' They bend over the clavicle. 'Only just fused.'

Almost all our cases are young men, aged between twenty and thirty. We don't see much variety in age or sex.

Sex is established through study of the pelvis, the skull and its mandible. The femur and humerus can also be measured and compared with international standards. Some skeletons do not appear exclusively male or female, showing features of both in shape and size, with both gracile and robust features. Sexing a skeleton may be only the sum of various features, tending more towards the female than the male, somewhere on a fluid scale. Kavita and Kundi run their fingers over curves and dents on the bones, sensing their arc. Their determinations arise from both measurement and experience.

Injuries are documented and photographed, and small red arrows are placed against the bones marking sites of trauma. The nature of fractures (keyhole or 
butterfly) can indicate something of their cause: blunt force, sharp force, high- and medium-velocity projectiles, all crack and break the bones in different ways.

$\mathrm{He}$ is photographed. Kundi climbs on a chair and leans over the skeleton with the camera. He is done.

The skeleton has no odour except the mild scent of soil, as neutral as stone. The bones are a mottled brown, tan and beige, stained by the earth that has leached its colours onto their exterior. If not too eroded, though, the surface below is a creamy alabaster, as flawless as the day they were born, as luminously pale as the weather-blanched animal bones we find in the veld, as cool and milky as marble, with both its rough and smooth textures. The bone's chalky mix of calcium and collagen is woven into a fine mineral matrix, a blend of both strength and flexibility. Cow-bone ash is what gives fine bone china its soft white colour: the finest porcelain contains no less than thirty per cent bone ash. In a paint palette, bone white is the colour of old lace, an ageing manuscript, bleached sheets, a white softened with a little yellow or grey. It is a gentle colour, infinitely human, infinitely animal.

His skeleton is made up largely of cortical or compact bone, a hard armature with the tensile strength of cast iron, so dense that a handsaw struggles to cut through it. It was his cargo carrier, the framework on which he was suspended. His bone shapes are smooth and cylindrical in the limbs, gently spherical on the skull, undulating on the scapula, curved on the ribs.

Nestled within his cortical bone is spongy bone - light and porous, pitted like a honeycomb with a delicate pale lattice of cells. Its spiny lace fills the ends of the long bones, the vertebrae and the inside of the ribs, the space between the outer and inner shells of the skull. In life, the ball of the hip was filled with red and yellow marrow. Now it is a dry orb of white cancellous mesh, its thin filaments surprisingly strong.

Spongy bone crumbles first under the assault of time and movement. Even while laid out on the table, tiny gossamer pieces of trabecular bone fragments are shed. Each time a bone is picked up or moved, a little more is lost. We have arrested his decay, seized him from the earth, but his disintegration cannot be entirely halted. We, the living, also shed some of our elements constantly, losing hair, skin cells. It can't be helped.

The bones contain the last of his unique markers as a human and an individual: his DNA. Under the right conditions, it can last for centuries, aeons even. We are rarely so lucky. DNA corrodes along with the bones in soil. Like an aircraft transponder signal, DNA becomes quieter, weakening as time passes, fading to a partial and incomplete set of markers, until at last it is gone.

We have an idea of who he was in life, and must take DNA samples from his remains to compare with samples from possible family members. The police's DNA lab is not yet producing good results for bone, so we send our samples abroad. They are too degraded, old and scarce to risk failed attempts. 


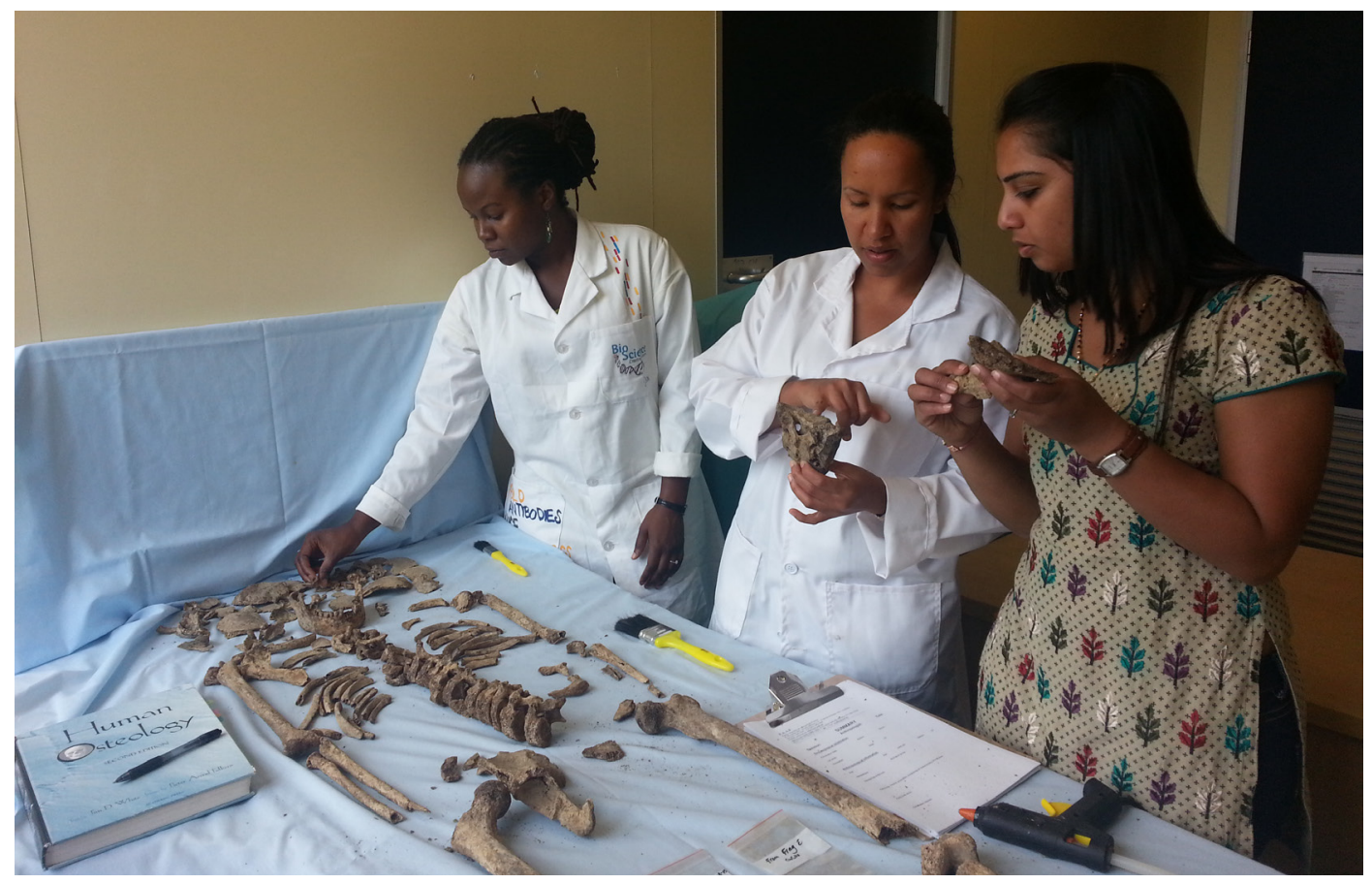

Forensic anthropologists from the National Prosecuting Authority's Missing Persons Task Team Kundisai Dembetembe, Colonel Laché Rossouw and Dr Kavita Lakha (L to R) examine the remains of one of the missing. Photograph by Madeleine Fullard.

We send samples to Bode Technologies, a private DNA laboratory in the USA, to the International Commission on Missing Persons laboratory in Sarajevo, and the Argentine Forensic Anthropology Team's small laboratory, run by Carlos Vullo in central Argentina's Cordoba province.

Claudia scrutinises the skeleton to select the best parts for sampling. The dental pulp inside the teeth offer the best source of DNA. Protected by the jaw and still nested in their sockets, the teeth are better shielded from degradation than the rest of the skeleton. The tooth itself provides a protective armour for the pulp inside.

She examines each tooth, looking for those without cracks or cavities. Some of the teeth are loose while others are still firmly embedded in their sockets.

'He has excellent teeth', she says, as she almost always does. Missing people in our part of the world don't have many advantages, but good teeth is one of them.

She selects four chunky molars that still have their roots attached. Three are easily removed, but one requires some force. She grips the loose mandible with one hand and strains, grimacing, to pull the tooth out with the other, like a dentist. It takes a couple of hard pulls; the patient is uncomplaining.

A sample bone is cut to accompany the teeth as a back-up. Bone DNA technology is now entering its second decade and laboratories are learning which parts of the bones retain or yield the most DNA. The cortical bone is best, strongest in places 
where it has borne the full weight of the body - the femur in the upper leg, the tibia in the lower leg, the talus in the ankle. Spongy bone is too porous and contains too little DNA.

I've asked Claudia to train us in cutting bone samples, and we are circled around her, watching. She selects the femur with the best preservation, without fractures, thick and solid.

'Here', she says, passing the femur around. 'Feel the solid weight of this one.'

We hold the bone and feel the heavy mass that speaks to good bone density within. A desiccated femur would be light and unsubstantial.

She picks up her Dremel tool. For aesthetic reasons, she will cut from the back of the femur so that, later, when we lay him out in a coffin, the cut section will not be visible when his family views his remains. Holding the femur firmly with one hand to keep it still, she lowers the buzzing circular saw onto the bone. A fine dry powder instantly billows into the air. It has a burnt, singed odour, more pungent than that created by a dentist's drill pulverising parts of a tooth into dust debris in one's mouth. The pervasive odour is carried on filmy grains into the air and a fine bone talc settles all around us. A face mask does little to keep it at bay.

We each take a turn with the Dremel tool, learning to control both the femur and the spinning blade at once, sensing how much pressure to apply, getting used to the milling sensation and the scent of cut bone. A window is cut through one surface of the bone through to its hollow core: top, bottom and two sides. When we are done we have a neat rectangle of solid cortical bone, like a long domino or tablet and a little curved, perhaps three by ten centimetres, that can fit in your palm. 


\section{TIME}

We have many enemies. Stony flinty soil blunts our spades. Thick wet clay smothers bones and grips our boots so tightly that they must be dug out. Tree roots imprison bones in latticed cages. Acidic soil erodes bones and leaches out the last of their DNA. Rain storms, blistering heat, a water table so high that bones are flooded and we must work blind, groping below the water surface, reading the bones with our fingers as if they were braille. We are in combat with space and time; time is the worse of the two.

In the early years of our work, physical conditions seemed to be our main adversary. As for time, there are no lives to be saved now. These deaths took place twenty, thirty, years ago. The past we seek is frozen, the bones are immobile, wherever they may be. A skeleton disintegrates so slowly that a year makes little difference. If I fret about a skeleton we must dig for, Claudia reassures me. 'Relax. He's not going anywhere. If he's there, we'll get him eventually'.

He's not going anywhere. But within a few years we learn that everyone and everything else is. We're all departing, corroding, in a relentless entropy. Everything around us is disintegrating, decomposing. Each place we go, everything we touch and every person we meet is unstable, dying off. Our cases may be decades old, but we are in a breathless race against time. Impermanence is our most deadly foe.

I learn that there are two domains of space and time. There is the motionless past we seek, a moment where space and time intersected, like $\mathrm{x}$ and $\mathrm{y}$ co-ordinates on a graph, or clues to a treasure hunt whose location never changes: the angle of a bullet, a spot beside a river. This is permanent: the place and time of death. Then there is our time, this time, now, draining like water through our grasping hands.

A cemetery presents itself as a place of ultimate immobility. What is a graveyard but the end of time? Yet it evolves, here erupting, there decaying, as if it were a living organism. Five years after our last visit to Winterveld, we take the now-familiar drive up the R81, passing through Soshanguve, through Mabopane, until the urban markers end, the homes thin out onto bigger plots and goats appear on the road. There, a sign on the left says Winterveld.

We're terrifically excited to see it again, a place whose familiar disorder we knew so intimately. But our arrival in a whirlwind of dust on the old gravel road is met by a new palisade fence. Winterveld Cemetery is a stranger to us, the old graves wearing a crisp coat of shiny fresh tombstones. We wander through the long grass, looking for graves we remember. Here and there, a cry of recognition. 'Here's Mr Masango!' whose tombstone we leaned against and whose stony flat exterior provided a table for our water, our tools. We look at Mr Masango with nostalgic fondness. But Winterveld has outgrown us. Our maps don't match its form any longer. The poisonous milky euphorbia tree is still there, heavier and wider, but where is that little path? Winterveld continues to slip through our fingers. 
A cemetery has parallel time zones set to different clocks. Below the earth, where microscopic changes take place in slow motion, and decay advances in tiny imperceptible measures, a skeleton may last for decades, even outstripping our life span. But above the ground, humans, animals, nature and weather perpetually rework the spaces.

In Sinathing Cemetery in Pietermaritzburg, which we visited in 2005, during the first few months of our work, the cemetery caretaker confidently points to two flat spaces on a sloping overgrown hill: here two MK members shot dead by police in April 1988 were buried. Only a few scattered tombstones identify the bushy incline as a cemetery. Otherwise, nature has reclaimed the terrain as its own. A public exhumation ceremony with the premier of the province and the local mayor is planned. Our head, Anton Ackermann, shakes his head. 'You'd better check those graves first. Imagine you open them in front of all those politicians and the families and they're the wrong graves?'

Claudia and I hastily open the two graves with a team of workers. Below, the remains are covered with blankets: both were family burials. The cemetery caretaker, embarrassed, suggests it must be the next two graves. After eight graves with blankets are opened, it is clear he is mistaken. He has used a gleaming new tombstone by the road as his marker and counted out graves from there. Tramping through the grass we find an old and faded but still readable tombstone, barely visible. We use it as a baseline to reconstruct the rows and determine the correct location of the two graves. The caretaker is out by two rows and a dozen graves to the left. The shiny new tombstone, wrongly positioned on an old grave, had created a disastrous domino effect, replicated across the cemetery.

We learn to regard tombstones' monumental certainties with suspicion. Many headstones are erected years, even decades after a death, and the identification of gravesites, based on vague memories and patchy records, is prone to uncertainty. Cemetery caretakers, the arbiters of space in whom all trust is placed, along with undertakers hired by families to erect tombstones, are key culprits in the misplacing of tombstones over the years.

In time, we become proficient in recognising tombstone styles and their epochs of popularity. The old ones, plain and worn, are more reliable. A gaudy new granite stone parading on a grave that is decades old is a fraud - a flashy gangster in a shiny suit.

On our first trip to Mbaleni Cemetery in Thohoyandou, to find the bodies of the five MK members who were killed in the March 1988 'Battle of Mutale River', green foliage strains and heaves like a jungle, hiding the graves beneath tall thick bush. Part of the former Venda bantustan, the area is lush, almost tropical, with mango trees, bananas, avocados, and macadamia nut plantations. Its exuberant greenery has taken over the older parts of the cemetery. Foliage must be slashed back by teams of workers with pangas. Plunging in like explorers of sites of antiquity, we open graves, checking their occupants until we find several with multiple bullet wounds, wearing fragments of identical overalls and boots. 
On our return a month later to exhume the remains, the graves appear to have disappeared. Our hand-drawn maps - here a tree, there a faded tombstone, there a pile of stones - no longer match the space. An invisible magician has transformed the environment.

'What the hell is going on?'

It takes us some time to realise that someone has erected a tombstone for their grandmother over one of our identified graves. It is covered with tarpaulin, awaiting an unveiling ceremony. Around the grave, stones and foliage have been rearranged, this and that moved out of the way.

It takes us a day to trace the family, to argue with them and the municipality, to convince them that their grandmother is buried a few graves over to the right. The cemetery book's entries are desultory, intermittent and unreliable.

'We opened this grave last month. There's a young man with bullet wounds in here. Now come see here, this side. There is an old lady buried in this grave. We checked it. She's so old she's lost most of her teeth. This must be your grandmother. You see, back in 1988, the cemetery people didn't write in the MK guys buried here in the cemetery book. The numbers jump. You see this gap? They didn't write them in the book. You've put the tombstone in the wrong place. It must be moved.'

The municipality is afraid to act. It becomes acrimonious. I have an exhumation order, a legal paper.

Our team look at each other: 'Let's do it.'

We dismantle the new tombstone with hammers and chisels, chip it out complete, undamaged, heaving its granite parts aside, and digging out our MK member beneath. It's surprisingly easy to dismantle a tombstone. Its solid segments, apparently built for eternity, are held together by thin layers of cement that can be dislodged with the tap of a tool.

The documents we need - police records, mortuary registers, cemetery books - drift away from us like planets, further and further into galaxies of oblivion. In 2005, police dockets from the 1980s could usually still be found in the back room of a police station. By 2010, they are in an outbuilding in damp piles with rats and cockroaches. In 2015, the police and administration staff are all new and no one knows anything about boxes. It is as if they never existed.

The pages of the cemetery books loosen, come adrift and disappear. Names beginning with $\mathrm{A}$ and $\mathrm{Z}$ (the front and back pages) are doomed, often long gone. $\mathrm{B}$ and $\mathrm{C}, \mathrm{W}$ and $\mathrm{Y}$ are now eroding. In 2007, Mamelodi Cemetery records straddling two decades were partly housed in a large box - almost hip height - containing a heap of random loose pages. Ten years later, those pages have eroded to half their former height.

The municipal office in Piet Retief's Thandukukhanya township stores the sole copy of the cemetery book. It is handwritten. 'What if there's a fire?' I ask the man at the desk. 'Make a copy of the book! Type it up!' A few years later, the office is burnt down in a service-delivery protest. The book goes up in flames.

In Durban, we spend two humid days in a baking-hot shipping container, sorting out heaps of post-mortem records from the 1980s and 1990s - documents that 
carry key clues and markers of identification. Dripping with sweat, we heave and sort them into years. The documents will be vital for our KwaZulu-Natal cases. A few months later, our Durban colleague Deborah Quin phones, distraught. The postmortems have been taken for paper pulping by a policeman at the station. They have been destroyed.

'All of them?' I ask in disbelief.

All of them. I have to lie down on the floor of the office as if the weight of the news is too much to bear standing up.

Most fragile and impermanent are the human beings. Ntuzuma Cemetery is now a vast grassy hill so overgrown you might never imagine it was a cemetery, were it not for perhaps five or six scattered tombstones. The old man who worked here is the last person who has a sense of its structure. There is no map. It fell under KwaZulu's bantustan authorities, and records are scarce. 'Where is N Section?' He walks and paces about, hither and thither, across bushy fields that hide a multitude of skeletons and pauses at an indistinguishable slope. 'Here: this is N Section.'

He has long retired to his homestead. 'Please,' I say to him, 'try to draw a map.' I don't want to say to him that he could drop dead any day now. He has spent his life burying fellow humans, young and old, but the suggestion that mortality may apply to him too seems unkind.

But it is the families, especially the mothers, who wither and die in the waiting, who set a clock in motion whose unbearable ticking wakes me in the night, sweating in a panic about a case that is thirty years old. My phone rings and I see the name on the screen, and I have nothing to say, nothing to report, no progress, no hope. The daughter of Mrs Kondile calls me to say her mother has had a stroke and is bedridden. A mother calls me on Christmas Day. 'Have a happy Christmas!' she says. I know she calls because she is thinking of her child, and we are a link to him and the possibility of his recovery. Her intentions are warm, but she casts a pall across my Christmas lunch.

Not only the families but the witnesses and perpetrators are departing into oblivion, doors slamming behind them. Every member of the old Western Transvaal Security Police division is dead. The Eastern Cape division is also decimated. Willem Schoon, one of Eugene de Kock's predecessors at Vlakplaas, has Alzheimer's. 'Sometimes he recognises me,' one of his former colleagues who lives in his street tells me, 'but most days not.'

If everything and everyone could just stay still, in one place, we could do our work. Instead, time robs us perpetually, inflicting random and merciless defeats. 